\title{
ESTIMASI DAN VALIDASI ASAM AMINO METIONIN, LYSIN, DAN THREONIN DARI PAKAN BIJIAN SEBAGAI SUMBER PROTEIN NABATI
}

\author{
Estimation and Validation of Methionine, Lysine, and Threonine Amino Acids \\ from Grain Feedstuff as Protein Source \\ Andri*1), Rahmad Perkasa Harahap ${ }^{1)}$, dan Yuli Arif Tribudi ${ }^{1)}$ \\ 1) Program Studi Peternakan, Fakultas Pertanian, Universitas Tanjungpura, Kota Pontianak, Kalimantan Barat, \\ Indonesia 78124 \\ Email: andri@faperta.untan.ac.id
}

Diterima Pasca Revisi: 27 Februari 2020

Layak Diterbitkan: 1 Maret 2020

\begin{abstract}
ABSTRAK
Kandungan asam amino dalam pakan biji-bijian menjadi titik kritis yang harus diperhatikan dalam kebutuhan nutrisi terutama unggas. Metionin, lisin, dan treonin harus tersedia dalam pakan untuk mendukung produksi unggas. Penelitian ini bertujuan untuk memperkirakan dan memvalidasi asam amino metionin, lisin, dan treonin dalam pakan sebagai sumber protein berbasis bahan kimia komposisi. Data komposisi nutrisi diperoleh dari basis data Feedipedia, terdiri dari 46 bahan pakan biji-bijian. Data termasuk konten Moisture, Crude Protein (CP), Crude Fiber (CF), Ekstrak Eter (EE), dan abu. Analisis korelasi dilakukan di antara komposisi nutrisi sebagai parameter untuk data bahan baku biji-bijian. Data kemudian secara acak dibagi menjadi dua bagian, bagian pertama (empat puluh enam data) digunakan untuk memperkirakan metionin, lisin, dan treonin sedangkan bagian kedua adalah data yang telah diamati untuk memvalidasi estimasi metionin, lisin, dan treonin. Hasil mengungkapkan bahwa persamaan prediksi metionin, lisin, dan treonin dalam biji-bijian adalah (1) $\mathrm{Met}=1,104-0,010$ Kelembaban - 0,005 CP - 0,027 CF + 0,012 EE + 0,091 ASH, (2) $\mathrm{Lys}=6,299+0,183$ Kelembaban -0,053 CP - 0,094 CF + 0,024 EE - 0,002 ASH, (3) Thr $=4,410+0,013$ Kelembaban - 0,004 CP - 0,029CF + 0,023 EE - 0,137 ASH, masing-masing. Nilai taksiran dan asam amino yang diamati dalam biji-bijian bahan pakan sangat mirip. Disimpulkan bahwa metionin, lisin, dan treonin dapat akurat Diperkirakan dari data komponutrisi.
\end{abstract}

Kata kunci: Broiler, lisin, metionin, pendugaan asam amino, studi literatur

How to Cite:

Andri, Harahap, R. P., \& Tribudi, Y. A. (2020). Estimasi dan Validasi Asam Amino Metionin, Lysin, dan Threonin dari Pakan Bijian Sebagai Sumber Protein Nabati. Jurnal Nutrisi Ternak Tropis, 3 (1) $18-22$
*Corresponding author:

Andri

Email: andri@faperta.untan.ac.id

Program Studi Peternakan, Fakultas Pertanian, Universitas Tanjungpura, Kota Pontianak, Kalimantan Barat, Indonesia 78124 


\section{PENDAHULUAN}

Pada formulasi pakan, peternak harus tahu tentang komposisi nutrisi sesuai dengan kebutuhan nutrisi ternak, seperti protein kasar, lemak, pati dan asam amino (AA). AA essensial merupakan asam amino yang harus diperoleh dalam ransum pakan ternak unggas. AA esensial seperti lisin dan sulfur yang mengandung AA (metionin dan sistein) harus mencapai tingkat yang cukup untuk memungkinkan performa ternak unggas yang optimal. Oleh karena itu, kandungan AA essensial di dalam bahan pakan ternak unggas sumer protein harus diketahui secara akurat.

Penentuan kimia AA individu dengan metode klasik menggunakan prosedur kromatografi cair tekanan tinggi memakan waktu dan mahal yang membuatnya tidak cocok untuk penggunaan rutin, terutama di negara berkembang. Metionin, lysin, dan threonine adalah asam amino yang menunjang produksi ternak. Metionin adalah AA yang mengandung belerang penting yang memainkan banyak peran dalam tubuh, termasuk (1) partisipasi dalam sintesis protein dan produksi asam amino yang mengandung belerang lainnya (misalnya homocysteine - AA yang mengandung belerang yang merupakan produk tidak langsung dari metilasi dan transkulturasi (Troen, 2003), (2) bertindak sebagai prekursor karnitin dan glutathione, sehingga membantu melindungi sel terhadap stres oksidatif(Fang et al., 2002; Li et al., 2007).

Studi ini menyelidiki model pendugaan AA untuk memperkirakan kandungan asam amino dari berbagai pakan unggas berdasarkan klasifikasi sumber protein nabati dan sumber protein hewani. Model yang diperoleh berdasarkan analisis multiple regression dengan mengumpulkan data sebanyak mungkin yang telah dikategorikan sumber protein hewani dan nabati. Kemudian, model ini akan diuji dengan nilai AA hasil laboratorium untuk mengetahui eror yang diperoleh. Tujuan dari penulisan ini adalah untuk memberikan gambaran yang dapat dipercaya tentang nilai nutrisi pakan unggas yang tersedia sebagai bahan pakan sumber protein nabati dari bijibijian untuk memberi saran kepada peternak tentang penggunaan pakan dan untuk membantu produsen pakan meningkatkan kualitas produk mereka.

\section{MATERI DAN METODE}

\section{Materi}

Dalam analisis ini dikumpulkan data yang telah diklasifikasikan berdasarkan bahan pakan sumber protein. Terdapat 2 klasifikasi bahan pakan sumber protein yang berasal dari nabati dan hewani. Pada analisis ini menggunakan data bahan pakan sumber protein nabati dari jenis biji-bijian dan kacang-kacangan.

Data yang diperoleh berasal dari www.feedipedia.org. Sebanyak 43 data bahan pakan sumber protein nabati yang dianalisis pemodelannya dengan multiple regression.

\section{Metode}

\section{Analisis statistika}

Kemudian untuk memperoleh model pendugaan AA digunakan analisis multiple regression, yaitu:
Keterangan:

$$
\mathrm{Y}=\mathrm{b} 1 \mathrm{X} 1+\mathrm{b} 2 \mathrm{X} 2+\ldots \ldots+\mathrm{bnXn}+\mathrm{c}+\mathrm{e}
$$

$\mathrm{Y}=$ variabel yang ingin diprediksi

$\mathrm{b}=$ koefisien regresi

$$
\begin{aligned}
& \mathrm{c}=\text { konstanta } \\
& \mathrm{e}=\text { error/residual }
\end{aligned}
$$


Analisis regresi dilakukan dengan menggunakan aplikasi statistika SPSS 20. Kemudian hasil yang diperoleh dilakukan challange dengan data laboratorium yang diperoleh dari hasil laporan analisis.

\section{HASIL DAN PEMBAHASAN}

Banyak faktor yang memengaruhi komposisi asam amino biji-bijian dan suplemen protein. Untuk mendapatkan ransum pakan yang akurat dan ekonomis, maka dalam formulasi ransum pakan harus mengetahui komposisi asam amino dari bahan yang sebenarnya untuk digunakan dalam ransum.

Namun demikian umumnya, tidak efektif dan effisien untuk menganalisis semua sampel bahan pakan sebelum digunakan dalam ransum. Oleh karena itu penelitian telah dilakukan di beberapa laboratorium menggunakan analisis regresi untuk memperkirakan komposisi asam amino dari bahan pakan yang dipilih dari komposisi proksimat mereka (Ward, 1989). Persamaan untuk memperkirakan kandungan asam amino dari bahan pakan yang terkait dengan perubahan kandungan protein disajikan pada Tabel 1 dan persamaan untuk memperkirakan kandungan asam amino dari komponen proksimat lainnya.

Pengetahuan tentang ketersediaan asam amino dalam bahan pakan penting untuk formulasi diet yang konsisten yang memenuhi persyaratan asam amino unggas. Jumlah asam amino yang tersedia untuk hewan sering jauh lebih rendah daripada kuantitas yang terkandung dalam bahan pakan. Banyak faktor yang mempengaruhi ketersediaan asam amino. Protein yang tidak didenaturasi sangat bervariasi dalam daya cerna unggas.

Persamaan ini (Tabel 1) mewakili pendekatan berbeda yang memberikan nilai koefisien dari banyak data yang telah diregresikan. Tidak ada upaya yang dilakukan untuk membandingkan hasil yang diperoleh dari menggunakan kedua set persamaan pada satu set sampel umum. Oleh karena itu persamaan yang diperoleh akan dilakukan challange dengan persamaan NRC 1994 yang dipilih berdasarkan bahan pakan sumber protein nabati dari jenis lupin bean, soybean meal,mug bean,peanut meal and fish meal.

Tabel 1. Persamaan untuk mengestimasimetionin, lysin, dan threonin dari komposisi nutrient pakan

\begin{tabular}{lc}
\hline Asam Amino & Persamaan Multiple Regresi Study \\
\hline Metionin & $M e t=1.104-0.010 \mathrm{KA}-0.005 \mathrm{PK}-0.027 \mathrm{SK}+0.012 \mathrm{LK}+0.091 \mathrm{Abu}$ \\
Lysin & Lys $=6.299+0.183 \mathrm{KA}-0.053 \mathrm{PK}-0.094 \mathrm{SK}+0.024 \mathrm{LK}-0.002 \mathrm{Abu}$ \\
Threonin & Thr $=4.410+0.013 \mathrm{KA}-0.004 \mathrm{PK}-0.029 \mathrm{SK}+0.023 \mathrm{LK}-0.137 \mathrm{Abu}$ \\
\hline
\end{tabular}

Keterangan: KA (kadar air), PK (protein kasar), SK (serat kasar), dan LK (lemak kasar)

Tabel 3 akan menunjukkan hasil perhitungan asam amino methionine, lysine, dan threonine dari persamaan yang diperoleh dengan data hasil penelitian yang di dapat. Berdasarkan hasil Tabel 2 dibawah ditunjukkan bahwa selisih eror tinggi terjadi pada bahan pakan fish meal hal ini terjadi karena data yang dikumpulkan berdasarkan klasifikasi protein nabati. Protein nabati yang diperoleh adalah bersumber dari jenis kacang-kacangan. Protein nabati yang lainnya yang dapat digunakan bisa berasal dari biji-bijian asal buah. Kalsifikasi berikut juga berdasarkan kandungan protein nabati yang memiliki kadar PK $>20 \%$, sehingga akan terjadi eror yang besar apabila persamaan ini digunakan untuk sumber protein $<20 \%$. Protein merupakan suatu zat makanan yang amat penting bagi tubuh karena zat ini selain berfungsi sebagai bahan bakar dalam tubuh juga berfungsi sebagai zat pembangun dan pengatur (Winarno, 2008). Lisin merupakan salah satu dari empat asam amino pembatas utama dalam ransum unggas. Asam amino pembatas lainnya adalah metionin, triptofan, dan 
arginine (Wiradisastra, 2001). Sebagai aditif dalam pakan, lisin memiliki interaksi dengan beberapa jenis zat, baik asam amino lainnya, mineral, enzim, atau kondisi fisiologis. Metionin terdapat pada buah- buahan, daging (ayam, sapi, ikan), susu (susu murni, beberapa jenis keju), sayuran (bayam, bawang putih, jagung), serta kacang-kacangan (kapri, pistacio, kacang mete, kacang merah, tahu tempe).

Tabel 2. Estimasi asam amino bahan pakan data hasil penelitian dengan persamaan multiple regression

\begin{tabular}{lccccccccc}
\hline \multirow{2}{*}{ Sampel } & \multicolumn{1}{c}{ Observed (\%protein) } & \multicolumn{6}{c}{ Present Study (\%protein) } & P-O \\
\cline { 2 - 10 } & Met & Lys & Thr & Met & Lys & Thr & Met & Lys & Thr \\
\hline Lupin bean & 0,7 & 4,8 & 3,6 & 0,82 & 4,73 & 3,4 & 0,12 & $-0,07$ & $-0,2$ \\
Soybean meal & 1,4 & 6,1 & 3,9 & 1,21 & 5,19 & 3,24 & $-0,19$ & $-0,91$ & $-0,66$ \\
Mug bean & 1,3 & 6,9 & 2,7 & 1,15 & 6,22 & 3,67 & $-0,15$ & $-0,68$ & 0,97 \\
Peanut meal & 1 & 3,5 & 2,5 & 1,2 & 4,62 & 3,22 & 0,2 & 1,12 & 0,72 \\
Fish meal & 2,8 & 7,5 & 4,1 & 1,99 & 4 & 2,57 & $-0,81$ & $-3,5$ & $-1,53$ \\
\hline
\end{tabular}

Asam amino metionin sangat diperlukan untuk kecepatan pertumbuhan dan hidup pokok semua hewan. Salah satu akibat bila terjadi kekurangan asam amino metionin adalah lambatnya laju pertumbuhan (Vázquez, 2006). Metionin berperan sebagai prekursor sistein dan ikatan yang mengandung sulfur lain (Almatsier, 2006).

Metionin juga penting untuk metabolisme lemak, menjaga kesehatan hati, menenangkan syaraf yang tegang, mencegah penumpukan lemak di hati dan pembuluh darah arteri terutama yang mengalirkan darah ke otak, jantung dan ginjal. Metionin sangat penting untuk mencegah alergi, osteoporosis, rematik dan toksemia pada kehamilan serta detoksifikasi zat-zat berbahaya pada saluran pencernaan (Harli, 2008). Lisin berfungsi sebagai bahan dasar antibodi darah, memperkuat sistem sirkulasi, mempertahankan pertumbuhan sel normal, menurunkan kadar trigliserida darah yang berlebih.

Kekurangan lisin dapat menyebabkan mudah lelah, sulit konsentrasi, rambut rontok, anemia, pertumbuhan terhambat dan kelainan reproduksi (Harli, 2008). Treonin terdapat pada bahan pangan yaitu susu, daging, ikan, dan wijen. Treonin dapat meningkatkan kemampuan usus dan proses pencernaan, mempertahankan keseimbangan protein, membentuk kolagen dan elastin, membantu fungsi hati, jantung dan sistem syaraf pusat serta mencegah serangan epilepsi (Harli, 2008).

\section{KESIMPULAN DAN SARAN}

Persamaan yang diperoleh hanya dapat digunakan untuk menduga asam amino yang berasal dari protein nabati. Bahan pakan protein hewani mengalami eror yang besar jika menggunakan persamaan tersebut. Persamaan tersebut juga hanya dapat digunakan pada protein nabati dengan kadar PK $>20 \%$. Asam amino essensial seperti metionine, lysine, dan threonine sangat penting untuk tubuh ternak unggas. Kadar asam amino dalam pakan harus cukup sehingga perlu akurasi pengukuran kandungan asam amino bahan pakan yang praktis dan akurat.

\section{DAFTAR PUSTAKA}

Almatsier, S. (2006). Prinsip Dasar Ilmu Gizi. Jakarta: Gramedia Pustaka Utama.

Fang, Y.-Z., Yang, S., \& Wu, G. (2002). Free radicals, antioxidants, and nutrition. Nutrition, 18(10), 872-879. https://doi. org/10.1016/S0899-9007(02)00916-4

Harli, M. (2008). Asam Amino Esensial. 
Li, P., Yin, Y.-L., Li, D., Woo Kim, S., \& Wu, G. (2007). Amino acids and immune function. British Journal of Nutrition, 98(2), 237-252. https://doi.org/10.10 17/S000711450769936X

Troen, A. M., Lutgens, E., Smith, D. E., Rosenberg, I. H., \& Selhub, J. (2003). The Atherogenic Effect Of Excess Methionine Intake. Proceedings of the National Academy of Sciences, 100(25), 15089-15094. https://doi.org $/ 10.1073 /$ pnas. 2436385100
Vázquez-AñÓn, M., Kratzer, D., GonzálezEsquerra, R., Yi, I. G., \& Knight, C. D. (2006). A multiple regression model approach to contrast the performance of 2-Hydroxy-4-methylthio butanoic acid and DL-Methionine supplementation tested in broiler experiments and reported in the literature. Poultry Science, 85(4), 693-705. https://doi.org $/ 10.1093 / \mathrm{ps} / 85.4 .693$

Ward, N. (1989). Regression Estimates Of Amino Acid In Ingredients. Feedstuffs.

Winarno, F. (2008). Kimia Pangan dan Gizi. Jakarta: Gramedia Pustaka Utama. 